\title{
The Many (Im)possibilities of Contemporary Algerian Judaïtés
}

\author{
Samuel Sami Everett
}

\section{La Criée Theatre, 1 April 2012}

On 1 April 2012 the final event of a three-day conference - 'La Guerre d'Algérie: 50 ans après' [The Algerian War: 50 years on] - took place at La Criée Theatre in Marseille. It was hosted by Maurice Szafran, ${ }^{1}$ who chaired a discussion between Bernard-Henri Lévy and Zohra Drif. In her opening address, Zohra Drif, a moujahida [female resistance fighter] of the Front de Libération Nationale (FLN) during the war of independence, introduced herself as a woman of Algerian, Maghrebi, Amazigh (Berber) and African origins, and of Arab-Islamic culture. Bernard-Henri Lévy - writer, philosopher, public intellectual, born in Algeria in 1948 - introduced himself as, above all, French. However, he also emphasized that he was the grandson of a Jewish shepherd from Tlemcen and in doing so seemed to implicitly declare an Algerian identity. Lévy's affective attachment and genealogical connection to Algeria are two factors that underlie an Algerian Jewish stake in the history and culture of the country beyond the question of juridical citizenship.

1 Szafran was the founder, with Jean-François Kahn, of the political magazine Marianne in 1997. The magazine sees its mission as offering an alternative to la pensée unique (a French expression that infers the predominance of a single worldview). 
It is to France that the vast majority of Algeria's Jews went in the months prior to Algerian independence in $1962 .^{2}$ And contemporary France has become an important site for a significant degree of Algerian JewishMuslim intellectual exchange and daily interaction. As with the positions adopted by Drif and Lévy, these forms of exchange are inflected by a broader politics relating to colonial historiography in France and in Algeria as well as transnational geopolitics - such as relations between Israel and Palestine and the 'War on Terror'. These discourses shape relations between 'Jews' and 'Arabs' in France to some extent. The complex question of Jewish Algerianness cuts across these dichotomies in interesting ways and speaks to contemporary North African multiculturalism (particularly in France) as well as to the tensions around difference and the possibility of differing loyalties which came to the fore during the Algerian war of independence and have re-emerged as a result of events in Algeria between 1988 and 1999.

The debate between Zohra Drif and Bernard-Henri Lévy highlights the fraught nature of remembering Algeria in contemporary France and the memory of France in contemporary Algeria, what these occlude and how they render Jewish identification with Algeria complex. Whether consciously or not, Drif's list of self-describing adjectives corresponds to an exclusively Muslim definition of Algerian identity. In what follows, I argue that it is this form of exclusivist positioning that obscures the more intimate realities and shared transnational proximities of personal experience that might reflect a subtler way of thinking through and acting out algerianités - a range of ways of belonging to Algeria, as locality or as culture - and how these intersect with judaïtés that are anchored within affective and political-historical positions. This chapter draws primarily from textual production by Algerian Jews as well as interviews with Parisian intellectuals of Algerian descent ${ }^{3}$ and is informed by the transnational impact of discursive constructs of nationhood prompted by key moments such as the Algerian civil war of the 1990s, the fiftieth anniversary of independence in 2012 and the supposed rise of Muslim anti-Semitism in France since 2001. ${ }^{4}$

2 According to Le Foll-Luciani, some 140,000 Algerian Jews left, the majority as 'repatriates' to France (2015: 8).

3 For my thesis I conducted ethnographic fieldwork in Paris between 2010 and 2012. During this period I interviewed a number of eminent Algerian Jewish intellectuals such as Brigitte Stora, Hélène Cixous and Benjamin Stora.

4 Several commentators and public intellectuals have, since the 1980s, become torchbearers of this particular argument. See Trigano $(2003 ; 2006)$ in relation to anti-Semitism. 
My aim is to rethink contemporary identification with Algeria by relating it to the historical experience of Algerian Jews and how this has been thought through and appropriated in national histories and by Jewish Algerians since 1988. After a short discussion of key terms such as judaïtés, the chapter is divided into three parts. Part one provides an insight into Algerian Jewish testimony of anti-colonial resistance and draws on my discussions with intellectual, singer and documentary-maker Brigitte Stora, who has explored the issue of Jewish Algerianness. Part two examines the identification, or non-identification, with Algerianness for Jews born in Algeria but now living in France. It reviews contrasting positions adopted by historian Benjamin Stora and sociologist and philosopher Shmuel Trigano. Part three pursues the relationship between Algerian Jews and Algerian history and culture through an account of the reception of the film El Gusto (2012) and its attempt to reinscribe Jews and Judeo-Muslim cultural practices into the national Algerian story.

\section{Judaités: \\ From Indigènes to Pieds-Noirs to Algerian Jews}

Hélène Cixous and Jacques Derrida, respectively born in pre-Second World War colonial Oran and Algiers, remained in Paris after the Algerian war of independence. ${ }^{5}$ Both are inhabitants of what Cixous would call a 'stranjew body' ${ }^{6}$ and both have consistently opposed the reification of Jewish 'religious' or Algerian 'national' identities that do not translate the diverse facets of complex and evolving identifications to multiple (North African and otherwise) localities and heritages. The neologism judaïtés - a deconstructionist term indebted to both Cixous and Derrida - gives expression to 'a certain equivocation, an indefinable and undeterminable diversity, that may well constitute the interiority of Judaism today' (Cohen and Zagury-Orly, 2007: xi). The complexity of judaités is historically layered: the term is not meant to define or explain but rather to act as a hermeneutic tool for opening up spaces of reflection.

5 Cixous and her mother did not move definitively from Algiers to Paris until 1971.

6 In her contribution to the colloquium 'Judéités: questions pour Jacques Derrida' at the Jewish community centre in Paris on 3-5 December 2000, Hélène Cixous, a close friend of Jacques Derrida, would make intertextual sense of their shared identification to a Jewish body, and the monolingualism of his/and their strange Algerian-born French (Jewish) body (Cixous, 2007: 75). 
Indeed, looking at Algerian Jewish nomenclature since the late nineteenth century, the importance of judaïtés as a non-teleological way of thinking through Jewish Algerianness becomes clear. The French colonial administrative term for Jews in Algeria was israélites as opposed to juifs (Lorcin, 2012: 904). This underlined a racial conceptualization of the North African Jew taken from French anthropology. Jews were at once tribal descendants from Israel in biblical Palestine, and israélites indigènes, simultaneously similar to, in their backwardness, but religiously distinct from, Muslims. Hubert Hannoun (2004) argues that the proposal of naturalization for Jewish and Muslim indigènes by the Napoleon III Senatus-Consultus of July 1865 (see Weil, 2003: 10) ended in failure with less than $5 \%$ of town-dwelling Jews seeking naturalization. It was therefore under the Third Republic that the salient disjuncture within Judeo-Muslim history was created by the 'ethnocultural' Crémieux decree of October 1870 (Savarese, 2002: 79). The decree imposed French citizenship en masse upon Jews across northern Algeria without taking account of Algerian Jewish choice (Schreier, 2010: 49). It was subsequently revoked under the Peyrouton decree in October 1940 in line with anti-Semitic policies pursued by the Vichy regime. This revocation of citizenship was followed by discriminatory policies relating to business profits and, later, property rights (Abitbol, 1983: 104). Following General de Gaulle's arrival in Algiers in June 1943 - in the wake of the Allied landings of November 1942 - it took a further five months for citizenship to be restored to the majority of the Jewish population in October 1943 (Le Foll-Luciani, 2015: 82).

Despite the anti-Semitic crimes of Vichy and the fact that there was no rush to reinstate citizenship, even after the military defeat of Vichy in Algeria, many Jewish people from North Africa would self-designate as pied-noir upon arrival in France. Pierre Daum defines pieds-noirs as 'all those non-Muslim French Algerians, that it is to say Europeans and Jews, who left or stayed' in Algeria (2010: 22). However, the term pied-noir, invented after Algeria gained independence (Shepard, 2006: 151), has both strong national-legal (citizen of France) and transnational, political (Algerian-born but 'repatriated to France') implications in its relation to Frenchness. ${ }^{7}$ Though a marker of Algerianness, the pied-noir label meant, and continues to mean,

7 Algerian citizenship was not offered en masse to non-Muslims who stayed in Algeria after 1962. Daniel Timsit explains that the Algerian state's requirement that non-Muslims undergo naturalization in order to obtain Algerian citizenship after 1962 was difficult to accept by those FLN Jewish Algerian activists who, like him, had been in favour of Algerian independence and had taken up arms against the colonial regime in the hope of helping to forge a new, plural Algeria (2002: 28). 
being a culturally assimilated French citizen (i.e., a speaker of French imbued with enlightenment values). However, since the turn of the millennium, many Algerian Jews have sought to dissociate themselves from the pieds-noirs (Allouche-Benayoun and Bensimon, 1999). This process can be read in tandem with the reappropriation of a certain Algerianness, often born out of a desire by Algerian Jewish liberals to self-differentiate from the settlercolonial implication of the term pied-noir, in addition to a distancing from the colonial period and its fraught historiography (Zytnicki, 2011).

This redefinition - from being French to being primarily Jewish Algerian - follows a general tendency towards atavism in religion that has taken place in French society since the 1980s (Hargreaves, 2007; Amselle, 2011). Such reinterpretations have also gained currency in traditionalist Jewish circles ${ }^{8}$ where transnational flows of people and ideas between Israel and France permeate peoples' lived realities (Schnapper et al., 2009). Traditionalist Jewish circles have often rejected the pied-noir label while concurrently distancing Algerian Judaism from Algerian Arabism and, by corollary, Islam. ${ }^{9}$ Such transnational, multifactor views of Algerian Jewish experience - as Israelites, pieds-noirs and Algerian - and their continual redefinition across France and Algeria renders more complex the assimilationist teleology prescribed by significant authors of Algerian Jewish history, such as Chouraqui (1972) and Ayoun and Cohen (1982), who saw Algerian Jews in terms of their movement towards French modernity.

\section{I}

\section{Jewish Algerian Anti-colonial Struggle and Algerian Citizenship}

Algerian Jewish anti-colonial political engagement also calls into question a teleological historiography that sees the Jews of Algeria naturally assimilated as French. It highlights how the politics of Jewish Algerianness was not ultimately of a sufficient scale to unravel the Arab-Islamic nationalism represented by

\footnotetext{
8 According to Erik $\mathrm{H}$. Cohen and Maurice Ifergan, Jewish traditionalists assign importance to societal values linked with 'authority, religious faith, founding a family, honouring one's parents' (2007: 138). Thus Traditionalism can be equated to a socially conservative outlook.

9 This was clear from contributions to the conference 'La présence juive en Algérie: Histoire et perspectives' [The Jewish Presence in Algeria: History and Perspectives] organized by the carefully named association Exode des Français Juifs d'Algérie [Exodus of French Jews from Algeria], which took place at the Palais du Luxembourg, Paris on 18 June 2012.
} 
the FLN movement and Algerian citizenship after independence. Mohammed Harbi argues that from 1956 onward the focus of the FLN was nationalist and that 'le nationalisme algérien était musulman' [Algerian nationalism was Muslim] (2011). ${ }^{10}$ This history of Algerian Jewish resistance to colonialism as a racial and structural ideology was further distanced from Algeria's official version of history with the argument for an exclusivist Islamic conceptualization of Algerian identity in the dark decade of the 1990s.

Recently the Musée de l'art et de l'histoire du judaïsme (MAHJ, Museum of Jewish Art and History) countered this view by incorporating Jewish anti-colonial figures into the broad-brush history of Jews in Algeria in its permanent exhibition. And, in terms of academic research on the subject, the work of Le Foll-Luciani is a comprehensive treatment of Algerian Jewish anti-colonial resistance from the 1934 Constantine massacre to 1962 (Le Foll-Luciani, 2015). The topic of Jewish Algerian anti-colonial resistance was also the subject of a radio documentary by Brigitte Stora in 2011. The Algiers-born Stora conducted interviews with a significant number of Jewish men and women who fought for Algerian independence. What emerges from her documentary is the sense that this anti-colonial engagement was predicated on a mythical Andalusi/Berber North African togetherness that informed spaces of rapprochement and zones of Judeo-Muslim commonality. These views are echoed in the prison diaries of Daniel Timsit, who fought for the FLN: 'Ce que nous gardions, c'était les fêtes et la musique. Mon père jouait au piano de la musique andalouse, il chantait, et quand il $\mathrm{y}$ avait des fêtes, nous invitions uniquement des orchestres de musique arabe classique' (2002: 13). ${ }^{11}$ Timsit's vision of the Algerian socialist project prior to independence coincides with other visions of a future, plural Algerian state, such as that of Ferhat Abbas, who promoted a heterogeneous Algerian nation that would acknowledge multiple historical lineages and navigate a myriad of cultural differences (Daoud and Stora, 1995).

By the end of the Algerian conflict of the 1990s, such a pluralist view and, specifically, Algerian Jewish reconciliation with the Algerian state, appeared almost impossible. Jewish relations with Algeria were trenchantly

10 Extracted from Harbi's contribution to Brigitte Stora's radio documentary 'Les Juifs d'Algérie engagés dans la lutte pour l'indépendance' [The Algerian Jews Involved in the Struggle for Independence], which was broadcast by France Culture on 20 September 2011. Brigitte Stora is not related to Benjamin Stora.

11 'What we had kept [of our indigenous status] were our celebrations and the music. My father played Andalusian piano, he sang and when we celebrated [religious and non-religious events] it was only ever classical Arab orchestras that we invited [into our homes]'. 
depicted by Jean-Pierre Lledo in his film Algérie: histoire à ne pas dire (2007). Lledo portrays virulent anti-Semitism in Algeria and its relationship to the violent Islamic extremism that drove him to leave Algiers in 1993. Lledo, a contributor to Shmuel Trigano's journal Controverses, has radically shifted his stance on the possibilities of a pluralist future in Algeria since leaving. Within the Algerian cultural and political context, the official distancing (indeed a form of 'othering') of a Jewish heritage from a sense of Algerianness is compounded by portrayals of returnee Algerian Jews from France as 'non-Algerians', or as pieds-noirs. This can be seen, for example, in the media coverage of the widely reported visit of several hundred Jewish Algerians from Paris to Tlemcen 24 May - 1 June $2005^{12}$ which followed on from President Bouteflika's agreement with President Chirac of France in March 2003 that sought to open up Algeria to non-Muslim tourism from France. Indeed, the narrative of a homogenous Islamic Algeria continues to be maintained by many in post-conflict Algeria. The Algerian Minister for Communication and Culture Khalida Toumi exemplified this in 2006 when, as the state representative at the Journée Arabe de la Culture [Arab Day of Culture] held in Algiers on 18 July, she outlined the main obstacle to any articulation of Algerian Jewish heritage in Algeria: 'La nation arabe fait face à des tentatives de judaïsation orchestrées par Israël qui altèrent des faits historiques et dénaturent certains aspects culturels arabes pour les présenter comme éléments de la culture juive' ('Quand madame la ministre dérape', 2006). ${ }^{13}$ Toumi's suggestion of a cultural colonization of Arab 'authenticity' by Jews results from a narrative that confuses Israeli appropriation of Palestinian lands with historically shared Jewish-Muslim Arab forms of art and culture. Her conflation of age-old cultural forms with current Israeli foreign policy places Algerian Jews outside the national narrative and reinforces the claim of a contemporary homogenous Muslim

12 El Watan and Le Quotidien d'Oran tend towards a standardized use of pied-noir (often instead of juif), rather than Israélite, which is rarely used. More recently, such as in its coverage of the burial of the actor Roger Hanin in Algiers, El Watan made indirect reference to Hanin's Judaism in relation to the neighbourhood Bab el-Oued, 'où les juifs et musulmans partagaient l'ambiance de ce quartier populaire d'Alger' [where Jews and Muslims shared the neighbourhood's working-class atmosphere] (see 'Hommage', 2015). My internet searches carried out in 2012 revealed that Echourouq and Al-Khabar use the Arabic yahud [Jew] only in relation to Israel.

13 'The Arab nation is faced with attempts of "Judaization", orchestrated by Israel, that alter certain historical facts and denature certain aspects of Arab culture in order to present them as Jewish culture'. 
Algeria. ${ }^{14}$ For his part, Lledo insists on anti-Jewish bigotry as a root problem in Algerian society and not as a consequence of a lack of critical intellectual engagement under authoritarian rule. Such deeply anchored ethno-religious perspectives from within the cultural ambit highlight the predominance of a religious frame in post-civil war discursive constructions of nation and how these define and construct, for example, 'Arab culture' in opposition to 'Jewish culture'.

This is the context informing Brigitte Stora's exploration of anti-colonial militancy of Jewish Algerians who were members of the FLN. Her documentary serves to unsettle historical narratives and presentist geopolitical positions that combine to divide Muslim and Jewish Algerianness. She remarks 'Or, elle [the history of Algerian Jews in the war of independence] n'a pas sa place dans l'histoire officielle [...] c'est une histoire qui n'existe presque plus ni en Algérie ni bien sûr du côté de l'état d'Israël et du sionisme qui considère que tous ces braves gens se sont plantés. ${ }^{15}$ The figure of the Algerian resistance fighter is central to the myth of Algerian national unity and yet it has resulted in the historical invisibility of Jewish fighters because their stories do not further the dominant nationalist narrative in Algeria or similar narratives in France and Israel. Stora continues: 'je ne pense pas que ce qui a triomphé devrait triompher, ça c'est une forme de déterminisme, une façon de penser que l'histoire a été écrite une fois pour toute et ça va à l'encontre de l'idée que tu peux agir sur cette histoire'. ${ }^{16}$ Those who participated in Brigitte Stora's documentary opposed the French colonial administration precisely because of its racialization of Jewish-Muslim social interaction. They were motivated by firmly held ideological beliefs that reflected their scepticism of French state humanism as practised during the Second World War.

The Arab, nationalist, Islamic and socialist discourses developed by the FLN in order to galvanize nation state identity were no doubt effective tools in building anti-colonial resistance. However, the hegemonic myth of national identity that was to evolve after 1962 largely excluded non-Muslims

14 At the same time, the Algerian state apparatus has been more open to the co-option of other identities, such as Berber language and culture.

15 Interview with Brigitte Stora, 22 October 2012: 'There is a near total erasure of their histories [of Jewish FLN resistance fighters] in Algeria, but the state of Israel also sees those valiant individuals as having got it wrong'.

16 Interview with Brigitte Stora, 22 October 2012: 'I do not think that that which won [after the war of independence] should have won. That is a form of determinism, a view of history as having been written once and for all and which goes against the idea that it can be acted upon, changed'. 
from the process of building a new Algerian nation. For Algerian Jews the sentiment of being a minority was ultimately compounded by a monolithic Arab-Muslim identity. Nevertheless, before 1956, it was the sentiment of minority injustice that guided the revolutionary attitudes of those Jewish men and women who believed that the pain inflicted by the Vichy administration should be channelled in ways that would serve all those oppressed by colonization. Le Foll-Luciani postulates that some of the more radical anti-colonial actors rethought and remodelled cultural forms of Algerian Judeity on this basis (2012: 81). Such a form of Algerian belonging ultimately proved impossible in Algeria due in part to the circulaire du code de la nationalité [nationality law] adopted in March 1963 that made non-Muslims born in Algeria foreigners (Le Foll-Luciani, 2015: 28). However, the mixture of depression and elation that accompanied their arrival in metropolitan France led to practices combining nostalgia for Algeria with a renewed sense of Jewish community, a process of remarginalization in France and the establishment of a new postcolonial minority position.

Thus, for many Jews who fought for Algerian independence, becoming Algerian went hand in hand with a projected sense of belonging to a utopian Algerian state. For Jewish communists - whose numbers were disproportionately high compared to Christian comrades (Le Foll-Luciani, 2012: 77) - the process meant at once an affective reappropriation of a Judeo-Arab past and an active political alignment with Algerian nationalism as an holistic experience rather than a commitment to the specifics of Algerian state policies (Le Foll-Luciani, 2015: 336). Such a cultural appropriation of Algerianness required being able to understand Algerian Arabic if not always to speak it. Many only spoke French - as Derrida puts it, 'je n'ai qu'une langue, ce n'est pas la mienne' (1996: 13). ${ }^{17}$ There is a sense among Algerian Jews that French has usurped Algerian Arabic but that its remnants nonetheless remain for people of Derrida's generation through a shared passion for Andalusi music (see Langlois, this volume).

As we have seen, being Jewish has become progressively more difficult to reconcile with being Algerian as a result of Algerian and French political contexts in the 1990s. Nevertheless, the standard postcolonial narrative of Algerian Jewry - shaped by the colonial bias that marks the literature on the subject (Chouraqui, Ayoun, et al.) and gives the impression of a natural 'progress' from indigenous folk to French citizens - has recently been challenged by a multiplicity of different historically, geographically and religiously situated stories that break down the idea of a homogenous 'Algerian Jewish' trajectory.

17 'I only have one language, and it is not mine'. 


\section{II}

\section{Identifying, or not, with Algerianness: Benjamin Stora and Shmuel Trigano}

As 'nearly-Algerians' - perceived from the outside as situated between Algerian indigenousness and French republicanism - the intellectual trajectories of Benjamin Stora and Shmuel Trigano, both well-established academics, elucidate the complexity of affective identity, geopolitical sympathies and nationalist affinities that have come to a head in France. This complexity has been marked by questions of community relations, France's legacy in its former colonies and the instrumentalization of French national identity under President Sarkozy between 2007 and 2012. Stora and Trigano were born in Constantine (1950) and Blida (1948) respectively and grew up in observant Jewish households. Since his public campaigning for mizrahi (Eastern Jewish) rights in Israel during the 1980s, Trigano has become a fervent proponent of Zionism and the mass immigration of Jews from France to Israel. In contrast, Stora's contemporary political engagement is focused on European diversity (2003: 17), highlighted by his position as Advisory President of the Musée de l'Histoire de l'Immigration [Museum of the History of Immigration].

Stora made a significant contribution to advancing recognition of North African culture and history in France during the 1980s. He allied himself to various initiatives that opposed the Algerian civil war of the 1990s and the manner in which it was represented in France (Stora, 1995). In addition, Stora's implicit, yet nuanced, sympathy for FLN leftism comes across clearly in his political memoirs published in the 2000s (2003; 2006; 2008; 2012). At the same time, Stora is forthright about his Jewish identity: 'je n'ai jamais cherché à nier ma judéité [...] tout le monde sait que j'étais juif, que je suis juif et que je l'ai toujours été'. ${ }^{18}$ This is worth noting as it makes clear that Stora does not deny his Jewish identity in order to visit and speak in Algeria. Finally, Stora's research unravels and critiques the Franco-Algerian 'memory wars' and the delegitimization of plurality by those who disparage it as a colonial cosmopolitanism (Plenel and Stora, 2011); a position that has led to the accentuation of nationalisms and the hardening of ideological positions in Algeria and France (Stora, 2008: 12). Furthermore, in line with Ferhat Abbas, Messali Hadj and Abdelhamid Ben Badis before him (notably in the 1930s), Benjamin Stora has maintained his commitment to a diverse Algerian nationalism. Since the inauguration of the Algerian archives at the Archives

18 Interview with Benjamin Stora, 6 July 2011: 'I have never sought to negate my Jewishness [...] everybody knows that I was Jewish, I am Jewish and I always have been'. 
Nationales d'Outre Mer [National Archives of Overseas Territories] in 2001, Stora feels that there has been a coming of age in France as the secondand third-generation descendants of Algerian Muslims seek to promote a memory that is plural and shared (Stora, 2012: 134).

By contrast, Shmuel Trigano objects to what he sees as Stora's reworking of colonial history in a way that presents Algerian Jews and Muslims as peacefully cohabiting over significantly long periods of time (Plenel and Stora, 2011). During the early 2000s, Shmuel Trigano argued that a new anti-Semitism' had come into being and was predicated on what he saw as a visceral and incommensurate anti-Zionism within Arab-Islamism (2006: 283). Trigano continues to be deeply concerned about the future of French Jewry in light of the increased anti-Semitic and racist acts in France since 2000 which, for him, are the result of European somnambulism in the face of a progressive 'Ottomanization' (2003: 115) of society. This view is partly predicated, he told me, on a pre-existing racial anxiety he developed in his youth in Blida. This rare moment of self-reflexive exposure allows us to better understand the blame he attaches to North African Muslims (his generalizing category for Muslims of North African descent living in France) for ethno-religious communitarianism in Europe even as he remains guarded about the implications of his personal experience as a member of a minority in French colonial Algeria.

Trigano has sketched the contours of a 'European Islam', outlining how governments should define a normative perspective for the sake of the non-Muslim European population (2003: 125-27). He draws on terms that have become part of a post-9/11 lexical field - for example Islam/terror as an intractable and singular concept - thereby contributing to an ideological terrain that presents anti-Zionism as one of the many facets of so-called new anti-Semitism. He pays particular attention to France - especially the purported danger from within the Paris region - where Jews and Muslims live side by side. Trigano is refitting his Algerian experience to the contemporary French metropole. He claims to see himself as having been a Frenchman residing in Algeria and his life in France as a continuation of that French existence 'over there'. His research findings regarding the position of French Jews as a minority fuse with his own mental image of life in Algeria. ${ }^{19}$

By contrast, Stora empathizes with the concerns of second- and thirdgeneration urban French Muslims of North African descent in relation to their views on the Middle East, but does not see it as fitting into a Jewish-Muslim sectarian continuum. Stora does not accept the label of French-Algerian for Algerian Jews, thus distancing himself from a strongly

19 Interview with Trigano, 12 September 2011. 
held belief among many Algerian Jews in France about the benefits of a Western conception of 'progress'. ${ }^{20}$ On the contrary, Stora argues that distancing oneself from Arab culture has been experienced as a form of cultural exile by Algerian Jews. ${ }^{21}$ For Trigano, the purpose of Stora's views is a rapprochement between North African Jews and Muslims in France, of which he is sceptical.

The positions espoused by Stora and Trigano differ greatly with respect to their views on Algeria, the feeling of Algerianness and solidarity with Algeria's people. Each has a form of judaïté that inflects an imagined relationship to North Africa, and a personal sentiment of belonging, or not, to Algerian history. Their contrasting positions give an insight into the ambivalence of what it is to be a Jewish person of Algerian origin in France today. Trigano's view is inward looking; experience has shown him that 'identity' and a moral framework should find their source in Jewish philosophy (Hyman, 1998: 209) and that Jews should look therefore to the Scriptures to develop conceptions of justice, progress and social relations (2012). By contrast, Stora adopts diverse ideas from different cultural and political sources. While these opposing views may be attributed to their differing politics, they are also a consequence of personal experience.

Firmly anchored in a French context informed by a colonial past and a multicultural present, Trigano rarely writes about his life or his political, emotional and academic trajectory, whereas Stora has published a well-documented autobiographical work on his Algerian 'return' (2003: 204) in which he reflects on his personal contribution to contemporary French plurality. Stora, often collaborating with others such as the Algerian historian Mohammed Harbi (2004), has managed to create space for discussion around minority inclusivity in Algeria. His work has been instrumental in promoting the historical inclusion of Jewish heritage within Algeria's national narrative. Pushing against this possibility of a connection between Algerianness and judaïtés, Shmuel Trigano deliberately elides Jew and Israeli, and consciously

20 I make this claim based on the 2012 MORIAL conference (MORechet Iehudei ALgeria) [Mémoires et Traditions des Juifs d'Algérie, Memories and Traditions of Algerian Jews], where the issues of progrès [progress] and enlightenment were raised by Emile Karoubi in his talk on Jewish involvement in the US landings in Algeria in the Second World War. These issues were pursued afterwards through questions from the floor. The conference, '2000 ans d'histoire juive en Algérie: 50 ans après ...' [2,000 Years of Jewish History in Algeria: 50 Years after ..., took place at the Centre Communautaire de Paris on 19 November 2012.

21 This is a view that Stora expressed at a conference held at Sciences Po titled 'Juifs et Arabes en France' in June 2009. 
promotes his views on Islamic anti-Jewish sentiment against which the Israeli state offers a safe haven for global Judaism and a bulwark against terror.

\section{III \\ Affective Identity: \\ Chaabi, Algerian Jews and the Grand Rex, Paris, 2012}

As we have seen throughout this chapter, Jewish affective identification with Algeria is bound up with the history and artistic culture (music, in particular) of Algeria. This view is supported by Timsit's comment (above) and by Benjamin Stora's career-long commitment to maintaining a notion of plurality (Jewish and otherwise) in Algerian history and promoting respect for North African minority cultures in France. However, this complexity is disputed by many, for example Trigano's conflation of Islam and terrorism views Algerian minorities in France as contributing to the breakdown of republican values and Algerian state ambivalence towards Jewish Algerian culture.

The recent Irish-Algerian film production El Gusto (Bousbia, 2012) is a documentary that seeks to reinscribe Algerian Jewish-Muslim conviviality, musical exchange and cross-faith friendship back into Algerian history. If the café indigène had the potential to be a site for transgressing the ethnic hierarchy that separated Jews from Muslims in colonial Algeria (Carlier, 1990), it is because it provided a mixed public space where people could listen and partake in shared musical traditions. It was a space of relaxation where Judeo-Muslim musical genres fused, becoming known in Algeria as chaabi (meaning 'popular' in Arabic). As such, Lili Boniche, an Algerian Jew and one of the great Algerian singer-songwriters of chaabi, was an obvious point of focus for El Gusto.

The documentary, which took over seven years to make, facilitates and tracks the reunion of the Jewish and Muslim members of a chaabi group from colonial Algiers known as El Gusto. The Jewish members went to live in France after the war of independence and the Muslim members stayed in Algeria. The first half of the film tells the story of chaabi as a musical form, its origins and, although less accentuated, its place within Algerian cultural resistance during the struggle for independence. The second half of the film concentrates on the lives of specific members of the group. The film ends with their first reunion concert at the Théatre du Gymnase in Marseille, in a kind of back-to-front story of return that brings out their passion and desire to transmit this shared musical form. And while the Algerian government allowed filming to take place in Algeria, the concert itself, it seems, had to take place in France. 
Chaabi music, steeped in Andalusi tradition, attracted Jewish Algerian singers such as Reinette l'Oranaise, Lili Labassi, Lili Boniche and others who developed the genre in Algeria and then in France after 1962. It 'belonged to the people' and was played in homes, cafés and in workingclass districts - hence the name the genre came to acquire. Historically, Muslims and Jews produced their own chioukh (plural for the Arabic cheikh) - musical leaders who would transmit classical repertoires to younger generations (see Langlois, this volume). For example, Hadj Si Mohamed El Anka, father of El Anka (junior) who appears in the film El Gusto, like Bashtarzi and Allalou, was a pupil of Cheikh Edmond Yafil. Squeezed in between full-blown oriental orchestras and café-concert style productions, chaabi music emerged between the two world wars and became a potent site for cultural gatherings by the 1950s, particularly in and around Algiers. Unfortunately, the Algerian war of independence ended its evolution as a shared Judeo-Muslim cultural form.

Although the group El Gusto's reunion takes place in Marseille, Algiers the city, its colonial buildings and the Casbah - captured in magnificent aerial views that also show parts that have fallen into ruin since 1962 - is one of the film's central characters. Algiers becomes a postcolonial lieu de mémoire [realm of memory] that can have a powerful visual impact on the audience. The Casbah - Daniel Timsit's working-class neighbourhood - with its innumerable steep and narrow alleyways and its plethora of bootleg goods and illicit substances - is seen as a key site of Algerian national resistance against the French colonial regime despite the fact that it has since been neglected by the government and some of its inhabitants. In the 1950s the Casbah was home to many cafés that had a reputation as places of ill repute as well as the city's oldest synagogue, the Djamaa lihoud [Jewish Mosque].

On 8 and 9 January 2012 at the Grand Rex in Paris, special screenings of El Gusto were followed by a Q\&A with the film's director, Safinez Bousbia, and a concert. In the queue, I heard people saying they had watched the film 'every night for a week'. Many cried during the screening and some spoke during the Q\&A. One young man said that after seeing Algiers again after 50 years his mother had spoken of her desire to return. He had booked flights and they would be visiting Algiers (for him it would be the first time) in less than a month. There were also sobering accounts of the difficulties of performing in Algiers during the 1990s civil war, when it was dangerous to play music. At the same time, a young man recounted that Salafi friends could not resist listening to chaabi because, they said to him, 'it is not music, it is part of us' even though strict Salafism does not permit listening to music. Some walked out in protest at the first mention of a 'war of independence' seeing it as a 'politicization' of the Q\&A - and my sense was 
that the protesters were unhappy to be reminded of 'the bad times' and may not have shared the view that 1962 signified 'independence'. Others, Algerian Jews and Muslims alike, stayed to ask the director questions about how she went about gaining Algerian government approval to film in Algiers. Bousbia is an idealist and, as she put it, a 'citizen of planet earth'. The success of her film, and the concerts and the debates that followed, provide evidence that friendship and cultural heritage remain ingrained in the social memories of Algeria's Jews and Muslims, refracted through Algerian Jewish and Muslim diaspora experience.

\section{Conclusion}

In light of the sustained, intensive bombing of the Gaza strip by Israeli air forces in the summer of 2014, the Algerian Minister of Religious Affairs annulled his declaration that the 25 remaining synagogues in Algeria would be reopened (Stein, 2015). However limited, it was a gesture towards exchange and an acknowledgement of Jewish culture within Algerian history. Nevertheless, Jewish identification with Algeria remains complex, freighted as it is by a long history and by more recent factors that have had a transnational reach, such as the violence in Algeria during the 1990s, the supposed reconfiguration of minority relations in France since 2000 and the fiftieth anniversary of Algerian independence in 2012. In terms of empathy and political solidarity, Jewish anti-colonial histories in Algeria demonstrate that it was, perhaps, possible for leftist Algerian Jews to reconstitute themselves within an overarching narrative based on a shared sense of cultural and political Algerian identity. However, the exclusionary laws on Algerian citizenship have, since the 'repatriation' of Algerian Jews to France, pushed Algerian Jewish intellectuals, sympathetic to Algeria, into an in-between position. Algerian-born but now Paris-based, public intellectuals such as Stora, comment on events in Algeria with empathy and often in ways that seek to counter the transnational consequence of a monolithic discourse on terror.

Transnational ethno-religious forms of identification among Algerian Jews and Muslims and their descendants in France are complex and necessitate historical distance and political open-mindedness. The complexity of Jewish Algerianness and the various positionings that this elicits can serve as an indicator of the difficulties that the contemporary nation state faces in establishing multicultural unity. El Gusto and other signs that the narrative of Algerian history might one day become more inclusive - such as the Tlemcen speech of 2002 or the reopening of 25 synagogues in 2014 - may be the first indicators of such a change in Algeria. 


\section{Works Cited}

Abitbol, Michel. 1983. Les Juifs d'Afrique du Nord sous Vichy. Paris: Maisonneuve \& Larose.

Algérie, histoires à ne pas dire. 2007. Dir. Jean-Pierre Lledo.

Allouche-Benayoun, Joëlle, and Doris Bensimon. 1999. Juifs d'Algérie. Mémoires et identités plurielles. Paris: Stavit.

Amselle, Jean-Loup. 2011. L'Ethnicisation de la France. Paris: Nouvelles Éditions Lignes.

Ayoun, Richard, and Bernard Cohen. 1982. Les Juifs d'Algérie: 2000 ans d'histoire. Paris: J.C. Lattès.

Carlier, Omar. 1990. 'Le café maure. Sociabilité masculine et effervescence citoyenne (Algérie XVIIe-XXe siècles)'. Annales 45.4: 975-1003.

Chouraqui, André. 1972. La Saga des Juifs en Afrique du Nord. Paris: Hachette.

Cixous, Hélène. 2007. 'This Stranjew Body'. In Bettina Bergo, Joseph Cohen and Raphael Zagury-Orly (eds), Judeities: Questions for Jacques Derrida. New York: Fordham University Press: 52-77.

Cohen, Erik, and Maurice Ifergan. 2007. Heureux comme juifs en France? Etude sociologique. Jérusalem: Éditions Elkana and Akadem.

Cohen, Joseph, and Raphael Zagury-Orly. 2007. Judeities: questions for Jacques Derrida. New York: Fordham University Press.

Daoud, Zakya, and Benjamin Stora. 1995. Ferhat Abbas, une utopie algérienne. Paris: Denoël.

Daum, Pierre. 2010. Ni Valise ni cercueil: les pieds-noirs restés en Algérie après l'indépendance. Arles: Actes Sud.

Derrida, Jacques. 1996. Le Monolinguisme de l'autre, ou, la prothèse d'origine. Paris: Galilée.

- - 2007. 'Abraham the Other'. Trans by Gil Anidjar. In Bettina Bergo, Joseph

D. Cohen, and Raphael Zagury-Orly (eds), Judeities: Questions for Jacques Derrida. New York: Fordham University Press: 1-35.

El Gusto. 2012. Dir. Safinez Bousbia.

Everett, Samuel Sami. 2014. 'Maghrébinicité 1981-2012: Affective Belonging from the Margins of North African Jewish Experience in Ile-de-France'. PhD thesis: SOAS, University of London.

Hargreaves, Alec G. 2007. Multi-ethnic France: Immigration, Politics, Culture, and Society. London: Routledge.

Hannoun, Hubert. 2004. 'La Déchirure historique des Juifs d'Algérie'. Le Quotidien d'Oran 24 June.

'Hommage. Roger Hanin: revoir Alger et partir'. 2015. El Watan 13 February. Available at: http://www.courrierinternational.com/dessin/2015/02/13/rogerhanin-revoir-alger-et-partir (consulted on 14 September 2015). 
Hyman, Paula E. 1998. The Jews of Modern France. Berkeley, CA: University of California Press.

Le Foll-Luciani, Pierre-Jean. 2012. 'Des étudiants juifs algériens dans le mouvement national algérien à Paris (1948-1962)’. In Frédéric Abécassis, Karima Dirèche and Rita Aouad (eds), La Bienvenue et l'adieu vol. II. Rabat: Centre Jacques Berque.

-—. 2015. Les Juifs algériens dans la lutte anticoloniale. Rennes: Presses Universitaires de Rennes.

Lorcin, Patricia M.E. 2012. 'Manipulating Elissa: The Uses and Abuses of Elissa Rhaïs and her Works'. The Journal of North African Studies 17.5: 903-22.

Plenel, Edwy, and Benjamin Stora. 2011. Le 89 arabe: réflexions sur les révolutions en cours. Paris: Stock.

'Quand madame la Ministre dérape'. 2006. Alger républicain September: 15. Available at http://www.algeria-watch.org/fr/article/tribune/ministre_derapage. htm (consulted on 14 September 2015).

Savarese, Eric. 2002. L'Invention des pieds-noirs. Paris: Séguier.

Schnapper, Dominique, Chantal Bordes-Benayoun and Freddy Raphaël. 2009. La Condition juive en France: la tentation de l'entre-soi. Paris: Presses Universitaires de France.

Schreier, Joshua. 2010. Arabs of the Jewish Faith: The Civilizing Mission in Colonial Algeria. New York: Rutgers University Press.

Shepard, Todd. 2006. 'Pieds-noirs, bêtes noires'. In Patricia M.E. Lorcin (ed.), Algeria and France, 1800-2000: Identity, Memory, Nostalgia. New York: Syracuse University Press: 150-63.

Stein, Sarah Abrevaya. 2014. 'Algeria's Jewish Past-Present'. Jadaliyya 11 September. Available at http://www.jadaliyya.com/pages/index/19205/algeria'sjewishpast-present (consulted on 9 October 2015).

Stora, Benjamin, and Mohammed Harbi. 2004. La Guerre d'Algérie: 1954-2004, la fin de l'amnésie. Paris: Robert Laffont.

Stora, Benjamin. 1995. 'Deuxième guerre algérienne. Les habits anciens des combattants'. Les Temps Modernes 580: 242-61.

- - 2003. La Dernière génération d'octobre. Paris: Stock.

-—. 2006. Les Trois Exils juifs d'Algérie. Paris: Stock.

- - 2008. Les Guerres sans fin: un historien, la France et l'Algérie. Un ordre d'idées. Paris: Stock.

- - 2012. Voyages en postcolonies: Viêt Nam, Algérie, Maroc. Paris: Stock.

Stora, Brigitte. 'Les Juifs d'Algérie engagés dans la lutte pour l'indépendance'. Radio documentary, France Culture. Broadcast on 20 September 2011.

Timsit, Daniel. 2002. Récits de la longue patience: journal de prison, 1956-1962. Paris: Flammarion. 
Trigano, Shmuel. 2003. Démission de la République: juifs et musulmans en France. Paris: Presses Universitaires de France.

- - 2006. L'Avenir des juifs de France. Paris: Grasset \& Fasquelle.

- - 2006-2009. Controverses, revue des idées. Paris: Éditions de l'Eclat. Available at http://www.controverses.fr/Sommaires/sommaires_index.htm (consulted on 20 January 2016).

——. 2012. 'La Condition des Juifs d'Algérie après L'exode de 1962'. Paper presented at Il y a Cinquante Ans, l'exode d'Algérie: 20 siècles de présence Juive. Conference, Palais de Luxembourg, Paris.

Weil, Patrick. 2003. Le Statut des musulmans en Algérie coloniale: une nationalité française dénaturée. Florence: European University Institute.

Zytnicki, Colette. 2011. Les Juifs d'Afrique du Nord. Paris: La Sorbonne.

Interviews in Paris (2011, 2012)

Benjamin Stora, 6 July 2011

Brigitte Stora, 22 October 2012

Shmuel Trigano, 12 September 2011 